\title{
Cosmopolitan Desire and Profitable Performance in The Dutch Courtesan
}

\begin{abstract}
The Dutch Courtesan reflects on the uses of seduction and desire in commercial culture. The eponymous courtesan Franceschina circulates among foreign clientele; the native conman Cocledemoy accumulates wealth through a range of foreign disguises. Their cosmopolitan appeal to diverse consumers illustrates the dangers of excessive desire linked to an intensifying fashion for foreign commodities in the period. The commodity that is the play itself also capitalizes on similar fascinations of London audiences. Franceschina and Cocledemoy's explicitly theatrical performances display and satirize how salesmanship - in the form of seduction and trickery - preys on consumer interests to fuel commerce in the global marketplace.
\end{abstract}

In cataloguing the clientele of Franceschina, the eponymous prostitute of John Marston's The Dutch Courtesan, the bawd Mary Faugh presents a grand tour of the continent:

I have made you acquainted with the Spaniard, Don Skirtoll; with the Italian, Master Beverone; with the Irish lord, Sir Patrick; with the Dutch merchant, Haunce Herkin Glukin Skellam Flapdragon; and specially with the greatest French; and now lastly with this English — yet in my conscience, an honest gentleman. $(2.2 .16-22)^{1}$

This inventory positions Franceschina as a global commodity, an object of desire, and a cosmopolitan figure since she is sought after and circulated among men from so many different countries without ever venturing outside of London. She is also a luxury commodity because the men among whom she circulates - dons, masters, lords, and merchants — are all socially elite figures. Mary Faugh, however, hesitates over what to call the English customer, unsure of his status. This

Liz Fox (efox@umass.edu) is arts and academic programs coordinator at the Kinney Center for Interdisciplinary Renaissance Studies, University of Massachusetts, Amherst. She also serves as editorial assistant for English Literary Renaissance. 
pause potentially makes an oblique reference to the Blackfriars playhouse audience, itself composed of English gentlemen or gallants masquerading as gentlemen who, like Franceschina's customers in the play, pay to view the courtesan. Franceschina is a sophisticated figure, and her experience with men from cultures other than her own is part of her appeal to fictional clients and London playgoers alike.

Cosmopolitanism, which Margaret C. Jacobs defines as 'the ability to experience the people of different nations, creeds, and colors with pleasure, curiosity, and interest', is one of the central interests of The Dutch Courtesan. ${ }^{2}$ Marston explores desire as an expression of cosmopolitanism throughout the play, which focuses on a pair of cosmopolitan figures who possess different kinds of theatrical skills that cultivate and exploit the desires of others. As a seductive foreign figure, Franceschina mesmerizes potential clients with her lute performances, vocal talents, and alluring dances. Meanwhile, Cocledemoy, the witty city companion, wields his theatrical skills differently, transforming his London identity into a range of foreign personas through a deft series of performative transformations. The appeal of both characters to a diverse set of consumers foregrounds the relationship between cosmopolitan desires and potential profits that threaten and attract consumers in a transnational marketplace. At the same time, the play is itself a commodity in London's marketplace, and Marston himself profits from the cosmopolitan interests of his audience members. This essay investigates the ways in which The Dutch Courtesan not only topically addresses concerns about the London consumer's desire for the foreign, but also capitalizes on that same desire among its Blackfriars audience members. The play both displays and satirizes the cosmopolitan desires that structure the cultural marketplace in which it first emerged. Through moments where desire, performance, and commerce intersect, Marston showcases the profitability of performance in a cosmopolitan context. In addition, he specifically presents the theatre as profitable because of its ability, like Franceschina's and Cocledemoy's, to repeatedly reinvent itself in ways that capitalize on London playgoers' cosmopolitan desires.

Although both Franceschina and Cocledemoy are highly theatrical characters that rely on seductive performances to exploit consumer desires, Marston inflects their theatricality with important differences. Franceschina is a theatrical figure who seduces her customers through salacious songs and lascivious dances. However, she lacks what Erika T. Lin calls 'theatrical privilege': the capacity to articulate awareness of the signifying processes through which theatre is made and the ability to manipulate such signifiers. ${ }^{3}$ When Franceschina seduces a client, she does not showcase the mechanics of her own theatricality by speaking to 
the playhouse audience, nor does she invite them to plainly view her processes of seduction. Unlike Franceschina, Cocledemoy is a theatrically privileged performer who underscores his own theatrical practice each time he transforms his identity, adopts a new costume, or alters his accent to create a new persona. Through his asides and direct addresses to the playhouse audience, Cocledemoy reveals the underpinnings of his performance to the playhouse audience. ${ }^{4}$ In addition to highlighting the signifying processes of his craft, Cocledemoy's asides foreground the range of profit he accumulates through his dexterous theatrical skills. From his theatrically privileged position, Cocledemoy exposes not only the signifying processes of the theatre itself but commercial processes as well. While Cocledemoy topically addresses the signifying and commercial processes of the theatre, Franceschina enacts them among the Blackfriars audience, her lack of theatrical privilege keeping her performances intact and exposing Marston's playhouse audience to the influence of her seductive skill. Critical work on The Dutch Courtesan has rightly emphasized the ways in which the play topically addresses London's 'increasingly cosmopolitan world of trade and traffic in goods'. ${ }^{5}$ I want to attend to the ways in which the play performs these same interests through Franceschina's and Cocledemoy's varying degrees of theatrical privilege because strategy and savvy for navigating the interconnected relationships among desire, difference, and commerce were important parts of what theatre offered its audiences while it catered to and exploited those interests at the same time.

Marston's characterization of a whore is particularly powerful with respect to the commercial interest and cosmopolitan features of the play. England's economic concerns about foreign trade and profit in the early seventeenth century connected directly to the threat of seduction by foreign luxury that whores such as Franceschina embodied. English merchants, as well as customs officials, who tried to understand the new rapidly developing global trade networks, sometimes characterized the relationship among London merchants, foreign commodities, and global markets as being reliant on seduction. For example, in The Customer's Replie (1604), Thomas Milles personifies the foreign market as a lascivious woman, attaching a tone of danger to transactions abroad through his colourful description:

And thus the faire Lady Merchandising Exchange enticed and allured the Merchant Adventurers of England, to procure themselves in fraternitie, and to seek meanes to plant their Marting Townes in a forraine Realme and Country, for the utterance of the commodities of the Realme, because they might make their returne and 
imployments, from thence into Englan[d], by the reckoning of Money currant in the said Merchandising Exchange. ${ }^{6}$

Lady Merchandising Exchange is whore-like in her seduction of potential customers as she tempts English merchants to foreign lands. ${ }^{7}$ At the same time, Milles associates Lady Merchandising Exchange with risk - she conflates the desire for sex with the desire for profit, which leads to other lusts and impaired judgments. ${ }^{8}$ She coerces English merchants to bring England's commerce to foreign realms, which was a concern for some who believed that spending abroad was essentially the same as exporting money, thus transforming domestic wealth into foreign profit, ultimately amounting to a loss of currency for England. ${ }^{9}$ The language of commerce and seduction intersects in alluring figures, like Lady Merchandising Exchange, who model the ways in which performative skills like seduction generated monetary profit in the emergent transnational economy. Popular narratives, too, frequently intimate English consumers' cosmopolitan interests in travel abroad and foreign fashion. Travel narratives in particular, as Linda Levy Peck explains: 'often reflect the seduction of the foreign and the fear of succumbing to the luxurious desires they created'. ${ }^{10}$ Giving into that desire 'involved not merely falling into worldly concupiscence and excess, but also enriching the foreign merchants ... at England's expense', according to Alison V. Scott. ${ }^{11}$ Thus, it fell on England's merchants, shopkeepers, and artisans to adapt quickly to the fluctuations of supply and demand - prompted in part by consumer desire - to preserve profitable exchange at home.

Prostitutes, and the sex industry at large, were no exception to reflecting the taste for foreign luxury among English consumers and modelled the rapid transformation necessary for industries to accommodate the shifting tastes of their consumers. In fact, the fashion for foreign luxury reinvented an entire sector of the sex industry as 'rooms became better furnished' and whores became more genteel - displaying skill with musical instruments or fluency with foreign language. ${ }^{12}$ The sex industry's ability to capitalize on the cosmopolitan desires of London consumers, moreover, attracted early modern playwrights, whose prologues, epilogues, and interludes document the frustration of pleasing the mercurial and varied tastes of their audiences. As the fashion for foreign commodities and thus foreign spending increased, Marston reflected on these consumer interests through the figures of the seductive foreign prostitute and the enigmatic city companion in The Dutch Courtesan to reveal that something beyond monetary profit drives the theatre: entertainment, pleasure, and wit. 
While Franceschina's Dutchness marks her as foreign, scholars agree that her identity and profession position her as a particularly complex cosmopolitan character. Franceschina's 'artful trade', as Jean Howard has argued, 'allows her to negotiate across national boundaries, bringing her profit, but resulting, ultimately, in deformity and incoherence. ${ }^{13}$ Similarly, Marjorie Rubright has claimed that since Franceschina is 'a Dutch courtesan with an Italianate name who is called every slang word for an English whore in the book, her ethnically-inflected differences, projected by those around her, resist a stable national and ethnic categorization.'. ${ }^{\prime}$ Andrew Fleck likewise emphasises that Franceschina's accent, behaviours, and dress similarly identify her as 'an unusual hybrid whose humorous admixture of Dutch harshness with Venetian elegance contributes to the comedy'. ${ }^{15}$

Franceschina's complex cosmopolitanism is the very quality that renders her attractive to potential clients and allows her to accumulate profit from a diverse range of clientele. Early in the play Freevill, newly engaged to be married, invites his resolutely abstinent friend Malheureux to the brothel, where he 'will show thee my creature: a pretty, nimble-eyed Dutch Tanakin; an honest, soft-hearted impropriation; a soft, plump, round-cheeked froe' (1.1.158-60). By first referring to her as his 'creature', a term that indicates a subservient relationship, Freevill situates Franceschina within an economic system of patronage. ${ }^{16}$ Freevill also commodifies difference by underscoring Franceschina's Dutch identity in his attempt to convince Malheureux of her appeal. Mary Faugh, too, celebrates Franceschina's considerable income from her rotation of elite customers, who are: 'not of swaggering Ireland captains nor of two-shilling Inns o' Court men, but with honest flat-caps, wealthy flat-caps, that pay for their pleasure the best of any men in Europe, nay, which is more, in London' (2.2.33-7). Importantly, Franceschina appeals to a wide range of clients by repeatedly reinventing and transforming herself when 'the wind is turned', a talent that draws on her complex cosmopolitan identity in a way that generates revenue (44). For Franceschina, 'turning' is a performative and lucrative skill that allows her to remain desirable to recurring clients such as Freevill and appeal to potential new clients like Malheureux. ${ }^{17}$ In this respect, Franceschina represents the sex industry as one that thrives precisely because of its ability to negotiate differences and reinvent itself in ways that appeal to the desires of diverse clientele, thus generating monetary profit.

Theatricality is integral to Franceschina's entertaining appeal. She evokes desire among her customers through a variety of performance types that seduce as they entertain. Each time she appears on stage she dances in a new style or performs with a different musical instrument (first on a lute and later with a cittern). Freevill twice refers to Franceschina as a siren: 'Come, siren, your voice!' and 'Siren, your 
voice, and away!' $(1.2 .117,124)$. The comparison between Franceschina and a siren suggests a potentially lethal relationship between spectator and spectacle, as Freevill likens her to the mythical feminine creatures that lured sailors to their deaths with enchanting melodies. Courtesan songs, too, were reputedly seductive to their auditors, urging their listeners to abandon common sense for sensual pleasure. ${ }^{18}$ The first song Franceschina performs suggestively compares herself to a nightingale, thought to sing more sweetly with a thorn pressed into its chest that prevented the bird from falling asleep and kept it singing all night (125-32). While the sexual innuendo of the lyric is obvious to readers, in performance, the physical posture required to play unwieldy stringed instruments such as the lute or cittern underscored the eroticism of the lyric. A musician had to sit with the instrument resting against her groin, legs slightly spread to accommodate the instrument's bulbous body. ${ }^{19}$ Following Franceschina's seductive lute performance Malheureux exchanges his puritanical antipathy for unbridled lust, undermining his original intention 'to make her loathe the shame she's in' (1.1.170). He instead wonders aloud, 'Is she unchaste? Can such a one be damned?' revealing the desire she evokes through seductive skill (1.2.141). As Malheureux ponders his newly awakened passions, Freevill eavesdrops on his friend's declamations of love for a prostitute, delivering asides of laughter at Malheureux's expense: 'Wa, ha, ho! ... By the Lord, he's caught! Laughter eternal!' (145, 155-6). Marston encourages playgoers to laugh at Malheureux not only because of his desire for Franceschina, but also because of how quickly such desire supplants his previously adamant opposition to the courtesan.

Malheureux's response to the lute performance also underscores the potential monetary profit of Franceschina's skill while foregrounding the corresponding threat foreign seduction presents to its domestic consumers. According to Malheureux's earlier characterization, Franceschina, like all prostitutes, is 'a money creature' and her singular desire for profit makes her a risky investment that could lead not only to fiscal losses but also physical and social ones by 'expos[ing his] health, and strength and name' $(1.1 .104,100) .{ }^{20}$ The humour of Malheureux's desire for the foreign whore vanishes when the symbolic danger and potential risk of Franceschina's siren-like seduction poses a legitimate threat. She convinces Malheureux to exact revenge on her behalf, vowing that she will not sleep with him until he has murdered her former patron-lover, his friend Freevill. That Malheureux initially agrees illustrates the economic threat posed by Franceschina's seductive power. Investing in revenge, according to Valerie Forman, is an investment in loss since loss becomes compounded in revenge plots. ${ }^{21}$ By presenting Franceschina as a seductive figure who manipulates consumers through lust and 
then tempts them to revenge, Marston highlights the potential losses associated with excessive desire for the cosmopolitan. At the same time, Marston makes his playhouse audience susceptible to the same excessive desires through Franceschina's staged entertainments.

What I want to suggest is that Franceschina's performance seduces her clients and the playhouse audience alike. ${ }^{22}$ In their conversations about Franceschina, Freevill and Malheureux employ a series of euphemisms that draw upon similarities between the theatre and sex industries. ${ }^{23}$ Malheureux calls the brothel a 'common house of lascivious entertainment' and the prostitute an 'odious spectacle,' while Freevill refers to the prostitutes' trade as a 'fleshly entertainment' $(1.1 .70,166,122)$. Through this series of euphemisms Marston calls his playgoers' attention to the fact that they are themselves in what was reputed to be a 'common house of lascivious entertainment' by virtue of their attendance at a play. Despite these similarities and Franceschina's overt theatrical skill, her lack of theatrical privilege increases the likelihood that playgoers attending The Dutch Courtesan will find themselves victims of Franceschina's seductive expertise. Here, Marston stages the very dynamics of the playhouse that anti-theatricalists like Stephen Gosson feared most, that the theatre seduced its viewers, luring them from virtue to vice. Gosson claimed that plays 'abroach strange consorts of melody, to tickle the ear; costly apparel, to flatter the sight; effeminate gesture, to ravish the sense; and wanton speech to whet desire to inordinate lust'. ${ }^{24}$ Marston, however, emphasizes that excessive desire provoked by pleasurable performance should be ridiculed rather than imitated, ultimately showcasing the theatre's ability not only to display for its audience this corrective, but also to enact it among them. Through Franceschina's provocative entertainments, Marston foregrounds his own medium's potential to seduce its spectators through charismatic performance, foregrounding the potential for both whores and playwrights to capitalize on their consumer's desires.

While Franceschina demonstrates the profitability of consumer seduction, Cocledemoy offers an alternative model for the profitability of performance in a cosmopolitan context. Cocledemoy, described in the 'Fabulae Argumentum' of the quarto text as a 'witty city jester', reinvents himself throughout the play into a variety of characters with different foreign accents and costumes (p 96). Like Franceschina, Cocledemoy is a complex cosmopolitan figure whose skill and familiarity with foreign types and customs allows him to exploit the desires of his victims, the gullible London vintner Master Mulligrub and his wife. Cocledemoy first disguises himself as a barber by coercing a barber's apprentice to lend him basin, razor, and apron. With his costume and props secured, Cocledemoy pauses 
to ponder the appropriate accent: 'Let me see — a barber. My scurvy tongue will discover me - must dissemble, must disguise. For my beard, my false hair; for my tongue - Spanish, Dutch, or Welsh? No, a Northern barber — very good!' (2.1.217-20). Cocledemoy settles on the Scottish persona of Andrew Shark, 'a former pedlar in Germany' presently serving as apprentice to a London barbersurgeon (2.3.30). This first moment of deception emphasizes Cocledemoy's status as a cosmopolitan figure by combining multiple layers of foreignness into a single character. The Andrew Shark persona and the numerous others Cocledemoy adopts throughout the play model performance as a profitable skill — he is limited only by his knowledge of foreign cultures and his ability to convincingly impersonate them.

Similar to Franceschina's performances, Cocledemoy exploits Mulligrub's desires with entertainment. Mulligrub reveals his own cosmopolitan desires when he pompously asks during his shave, 'And what's the news? How do all my good lords and all my good ladies, and all the rest of my acquaintance?' 'And what more news? You shave the world, especially you barber-surgeons; you know the ground of many things' (2.3.35-7, 62-3). Cocledemoy first shares a story of the conduit in Greenwich, from which snakes purportedly emerged, then transformed into mastiffs, then cocks, and then bears that are now available for viewing in Paris Garden. This outlandish story features examples of animal metamorphoses that emphasize the capacity for transformation to entertain. The gullible Mulligrub eagerly responds that he and his wife will go to view the spectacle, revealing the vintner's lack of sophistication despite his cosmopolitan aspirations. Cocledemoy's second narrative reports 'that twenty-five couple of Spanish jennets are to be seen hand-in-hand dance the old measures, whilst six goodly Flanders mares play to them on a noise of flutes', but this tale of spectacle arouses Mulligrub's scepticism (66-9). Quick to adapt to the circumstances, Cocledemoy soaps the vintner's face to end the conversation. In this first disguise as Andrew Shark, Cocledemoy's tales of shapeshifting and fantastical entertainment distract Mulligrub so completely that the knave places a coxcomb on the vintner's head, visually reinforcing Mulligrub's gullibility, and exits with a bag of the vintner's money. Similarly to Freevill's asides during Malheureux's sexual conversion scene, Cocledemoy's series of asides invite his audience to laugh at Mulligrub's foolishness by calling attention to the vintner's arrogance, referring to him as 'an arrogant knave' and 'worshipful fist' $(38,60)$. Cocledemoy perpetually reminds the Blackfriars audience of the joke and allows them to be 'in' on it.

Cocledemoy reinforces the profitability of performance each time he transforms his persona to con Mulligrub out of additional wealth and commodities. In 
a later instance, disguised as a French pedlar, Cocledemoy overhears Mulligrub's purchase of a silver goblet from Master Garnish, a detail that allows Cocledemoy to 'shave [Mulligrub] smoother yet!' (3.2.33-4). Capitalizing on this knowledge, Cocledemoy takes on the persona of Master Garnish's apprentice, stealing the silver goblet newly delivered to the Mulligrubs' home under pretence of additional work required at the shop. Cocledemoy again exploits the Mulligrubs' social aspirations, this time by suggesting to Mistress Mulligrub that the goldsmith and his wife 'will come to dinner to season your new cup with the best wine' (3.3.38-9). Enraptured by the thought of hosting elite guests in her home, Mistress Mulligrub hands over the goblet and, mere moments later, a jowl of salmon to the knave. Although she is eager to impress the goldsmith and his wife with her generosity, she instead appears foolish to Marston's audience.

As with Cocledemoy's other appearances, direct addresses and asides that invite the playhouse audience into his antics as the trick escalates pepper this scene. Cocledemoy colourfully informs playgoers that 'I'll gargalize my throat with this vintner, and when I have done with him, spit him out'; reminds himself to 'lurk close' to the vintner's tavern; and invites viewers to anticipate his theft of the salmon by self-reflexively proclaiming, 'Cocledemoy, now for the masterpiece' (3.2.35-7, 3.3.51, 3.4.72). Each aside includes Marston's audience in Cocledemoy's trick and encourages them to laugh at the Mulligrubs' lack of savvy. Although Cocledemoy transforms his identity from Scottish to English to French and back to English, he remains, as Jean Howard rightly argues, 'linguistically coherent whatever his disguise. A chameleon, slipping from register to register, he always emerges as himself'. ${ }^{25}$ In addition to linguistic coherence, Cocledemoy maintains consistent legibility as city knave through his theatrically privileged asides that invite the playhouse audience to view the costume as costume and indicate the ways in which the costume constructs difference. By foregrounding Cocledemoy's disguises, Marston offers a model for profitable transformation within a cosmopolitan context - one that is distinctly theatrical and profits through the pleasures of performance. The quantity and kind of things that Cocledemoy steals showcase the range of profit available through Cocledemoy's con - he accumulates commodities such as the silver goblet and the jowl of salmon in addition to the bag of coins. Through the different goods that circulate throughout Cocledemoy's plot, the play broadens what counts as profit, extending beyond the narrow definition of monetary profit taken in Franceschina's plot.

Cocledemoy's seductive methods are similar to Franceschina's in their theatricality despite the two figures' different livelihoods. Just as Franceschina appeals to her customers by singing or dancing in a new style or with a different instrument, 
Cocledemoy's knavery is a skilled and seductive performance that exploits the Mulligrubs' cosmopolitan desires in ways that lead to profit. Unlike with Franceschina, however, Marston highlights the metatheatricality of the tricks Cocledemoy plays on the Mulligrubs through this character's direct address and asides to the audience. The audience's amusement with Cocledemoy's tricks and transformations derives from the fact that, despite Mulligrub's effort to discover and punish Cocledemoy, he is unable to see through the theatrical illusion to the knave beneath it all. In short, Mulligrub is a witless spectator engaging with spectacle. Marston stages the actor-audience relationship through Cocledemoy and Mulligrub - playgoers pay admission for each new play although they view the same actors over and over as different characters, essentially paying for the pleasure of being fooled via an actors' skill in transforming themselves into something new.

Although initially pleasurable, like Franceschina's seduction of Malheureux, Cocledemoy's tricks with Mulligrub also turn threatening as they escalate. Cocledemoy first has Mulligrub put in stocks for the theft of a cloak. Then Cocledemoy, disguised as a bellman, reports to the constables that Mulligrub is 'a strong thief. His house has been suspected for a bawdy tavern a great while, and a receipt for cutpurses, 'tis most certain. He has been long in the black book' (4.5.120-3). Importantly, Mulligrub's alleged crimes are ones that, like Franceschina's revenge, reveal an investment in loss. While the accusation of running a bawdy tavern poses a risk to the social and moral fabric of London, as Malheureux initially claimed about Franceschina's trade in act 1, the accusation of being a 'receipt for cutpurses' poses potential monetary loss to the local economy. The crime with which Mulligrub is charged presents his tavern as a dangerous site of transformation - one that exchanges stolen goods for honest currency, a criminal offense that purportedly landed Mulligrub's name in a criminal record. Although many of Cocledemoy's pranks on Mulligrub involve lying and exaggeration, there is some truth to this accusation. 'Adulterated or poor quality foodstuffs', as Marjorie Rubright has argued, 'are at the heart of what aggravates Cocledemoy about the Mulligrubs.' ${ }^{26}$ The Mulligrubs speak openly about their tainted goods and cooked books throughout the play, such as when Mistress Mulligrub assures her husband that they will make up for the loss of the goblet easily, that "tis but a week's cutting in the term' (2.3.119). Significantly, Cocledemoy associates the Mulligrubs' criminal activity with the products served in their tavern, accusing them of diluting their wines, adulterating 'the true ancient British and Trojan drinks' with 'Popish wines, Spanish wines, and French wines', imports that are ultimately detrimental to the English economy (5.3.116-8). Mulligrub's tavern is, indeed, a site of complex cosmopolitanism wherein good products transform 
into bad at a loss to consumers. ${ }^{27}$ In a play deeply invested in the profitability of cosmopolitan attitudes in a global market context, the Mulligrubs mismanage their own cosmopolitan desires, and their tavern showcases the threat of potential economic losses at home through a cosmopolitanism that contaminates rather than enhances the quality of commodities.

Act 5 scene 3 offers yet another series of transformations and performances. In this culminating scene, Franceschina's and Cocledemoy's victims both face punishment for their crimes: Malheureux for Freevill's murder, Mulligrub for the range of unsavoury activities for which Cocledemoy has framed him. Although Freevill and Malheureux had planned to fake Freevill's death to punish Franceschina, instead Freevill crafted his own plot to punish Malheureux and cure his friend of unbridled lust for a whore. Now facing execution for Freevill's murder, Malheureux transforms his desire yet again, this time reverting to his original abstemious attitudes. He repents his desire for Franceschina, regrets his risk, and grieves for the resulting losses:

But now, though source of devils, oh, how I loathe

The very memory of that I adored!

He that's of fair blood, well-miened, of good breeding,

Best famed, of sweet acquaintance and true friends,

And would with desperate impudence lose all these

And hazard landing at this fatal shore,

Let him ne'er kill nor steal, but love a whore!

Malheureux evokes Franceschina as a threatening and dangerous figure whose 'fatal shore' menaces with foreign hazards. She is no longer a luxurious courtesan but is twice referred to as a 'fair devil' as Malheureux reimagines Franceschina as the siren-like Lady Merchandising Exchange (47). In these final moments, Marston emphasizes the impending risk that Franceschina has embodied throughout the play as an object of cosmopolitan desire. Hearing his friend repent, Freevill throws off his disguise and proclaims that his purpose was 'to force [Malheureux] from the truer danger' - his lust for Franceschina for whom he almost lost all (46). As the play resolves, the men attribute all accountability for the near murder to Franceschina. Since Malheureux was not wholly seduced into killing his friend and rejected her violent revenge well before Freevill decided to teach him a lesson, Malheureux escapes ultimately unscathed, having mostly experienced some fear and embarrassment. Freevill declares, 'only what you can think / has been extremely ill is only hers', and Franceschina exits the stage to be whipped and imprisoned (56-7). Marston ultimately identifies Franceschina's seductive power 
to exploit and manipulate her customers' desires as the central economic and physically destructive threat of the play that must be contained and condemned.

While Franceschina receives a sentence of violent punishment for her cosmopolitanism that threatens both economic and physical well-being, Cocledemoy cleverly escapes penalty for his similar skillset by passing it off as wit. When Mulligrub is about to be punished for his series of supposed crimes, the prosecuting sergeant urges the abused vintner not to press charges against Cocledemoy. Mulligrub excuses Cocledemoy, assuring the crowd, 'I forgive as I would be forgiven' (5.3.125-6). Only then does the Welsh officer reveal himself as Cocledemoy. Amid cries of 'knave' from onlookers, Cocledemoy defends his actions: 'No knave, worshipful friend, no knave! For, observe, honest Cocledemoy restores whatsoever he has got, to make you know that whatsoe'er he has done has been only euphoniae gratia — for wit's sake. [Gives back the goblets.] I acquit this vintner as he has acquitted me - all has been done for emphasis of wit, my fine boy, my worshipful friends' (146-52). Recognizing that he is about to be revealed as a thief, Cocledemoy returns the stolen goods and maintains that he never presented a legitimate harm to Mulligrub. Cocledemoy again employs his performance skills, this time revealing his disguise to all and ultimately returning to his original identity of the 'witty city jester' - a move that further showcases the economic advantages for Cocledemoy, and the amusing pleasures for playgoers, of his repeated transformations.

Cocledemoy's final change stages a more nuanced view of the economy by presenting the kinds of profit available in the theatre in addition to money. By staging a variety of ways in which consumer desire can be exploited for profit, Marston invites his audience to increase their own wit and cosmopolitan savvy through the playhouse. The actor playing Cocledemoy addresses the Blackfriars audience in a pseudo-epilogue that perfectly mirrors Cocledemoy's explanation for duping Mulligrub, calling the performance itself a 'hurtless mirth' performed for 'trivial wit' that does no actual harm $(175,177)$. These lines emphasize the extent to which the theatre itself offers pleasure, instruction, and wit, underscoring that the theatre is a commodity worth the monetary investment of its audiences. The theatre is edifying, as Cocledemoy corrects and punishes the Mulligrubs for their real crimes of cheating their customers and Malheureux is exposed for his continued sexual lust for Franceschina despite recognizing her as a danger. The pleasurable transformations that Cocledemoy displays model for Marston's audience a way to achieve mastery over their own cosmopolitan desires rather than fall victim to them. His skill and worldly knowledge, shared through asides and direct addresses, illustrate for playgoers different strategies by which they might 
avoid being victimized by the threatening, exploitative, and potentially destructive forces of Franceschina.

As Marston examines both the threat and attraction of cosmopolitanism and performance through the figures of Franceschina and Cocledemoy, he enacts this same seductive power through the theatre itself. Franceschina's performance is alluring and dangerously transformative. Her power to manipulate others' wants and to accumulate profit through her seductive performances plays on those same cosmopolitan desires of some in the audience. Franceschina is the central spectacle for whom his play is named. Its provocative title draws in customers, generating monetary profit for the Blackfriars playhouse and its investors. In the same way that Franceschina's seductive arts tempt Malheureux, Marston similarly tempts his playgoers. But by punishing Malheureux, Marston obliquely chastises his audience for their own cosmopolitan desires for foreign luxury that are implied through their attendance at a play called The Dutch Courtesan. Cocledemoy's performance is witty and pleasurably transformative - audiences have fun laughing at Mulligrub alongside Cocledemoy. His cosmopolitan and theatrical transformations harmlessly entertain and potentially educate as Marston invites his audience to view the commercial value of theatre itself. Marston integrates the courtesan's seductive arts and the city knave's tricks into his own artistic medium, capitalizing on his audiences' demands in ways that benefit the theatre industry while simultaneously offering a didactic rebuke of such desires through characters like Malheureux and Mulligrub. Cocledemoy, speaking from a position of theatrical privilege, ultimately teaches the audience to be wary of their own desires for cosmopolitanism by offering good and bad models of consumption. Being aware of, and having mastery over, one's own cosmopolitan desires enables Londoners to indulge their appetites for foreign goods without being harmed or causing harm to the English economy. At the same time, lack of mastery and awareness of cosmopolitan performances, as is the case with the Mulligrubs and to a lesser extent Malheureux, causes English playgoers harm when they participate in cosmopolitan exchanges without savvy. This participation is, in part, why theatre is a worthwhile investment. Marston can indulge his audience's desires without their risking actual economic or moral loss. Neither foreign brothels, foreign commodities, nor the play's indulgence of consumer desire for them are problematic; rather the naïve consumption of those pleasures without awareness or regard for the potential losses they create is a far greater concern. 


\section{Notes}

I would like to thank Adam Zucker, Marjorie Rubright, and the two anonymous readers at Early Theatre for their generous advice on earlier drafts of this essay.

1 John Marston, The Dutch Courtesan, ed. Karen Britland (London, 2018). All further references to the play are to this edition.

2 Margaret C. Jacob, Strangers Nowhere in the World: The Rise of Cosmopolitanism in Early Modern Europe (Philadelphia, 2014), 1.

3 Erika T. Lin, Shakespeare and the Materiality of Performance (Bastingbroke, 2012), 37, https://doi.org/10.1057/9781137006509.

4 Jeremy Lopez, Theatrical Convention and Audience Response in Early Modern English Drama (Cambridge, 2002), https://doi.org/10.1017/cbo9780511483714.

5 Jean E. Howard, 'Mastering Difference in The Dutch Courtesan', Shakespeare Studies 24 (1996), 115.

6 Thomas Milles, The Customers Replie, or Second Apologie (London, 1604; stc: 17932), D3r.

7 I use the term whore, prostitute, and courtesan interchangeably in this essay, following Duncan Salkeld's position that, 'the distinction should no longer distract us'; Shakespeare Among the Courtesans: Prostitution, Literature, and Drama, 1500-1650 (Burlington, 2012), 23, https://doi.org/10.4324/9781315608556. For discussion of how these terms and their relationship with sex, language, and meaning evolved during the period, see Stephen Spiess, Shakespeare and the Making of Early Modern Whoredom (forthcoming Oxford University Press). I would like to thank Professor Spiess for allowing me to view portions of this manuscript in advance of publication and for providing generous feedback on an early draft of this essay.

8 See, for example, Laura Mandell's discussion of consumerism as a vicious woman and bawds as merchants in Charles Mandeville's satirical defense of public stews in the early eighteenth century. Laura Mandell, 'Bawds and Merchants: Engendering Capitalist Desires', English Literary History 59.1 (1992), 107-23, https://doi. org/10.2307/2873420. For discussions of The Dutch Courtesan and women's role in the evolution of London's commercial status, see Jean E. Howard, Theater of a City: Places of London Comedy, 1598-1642 (Philadelphia, 2007), 114-61, https://doi. org/10.9783/9780812202304 and Sarah K. Scott, 'Discovering the Sins of the Cellar in The Dutch Courtesan: Turpe est difficiles habere nugas', Medieval and Renaissance Drama in England 26 (2013), 60-75.

9 Joyce Oldham Appleby, Economic Thought and Ideology in Seventeenth Century England (Princeton, 1978), 48. For more on the relationship between investment and the 
export of treasure, see Judith H. Anderson, Translating Investments: Metaphor and the Dynamic of Cultural Changes in Tudor-Stuart England (New York, 2005) and Valerie Forman, Tragicomic Redemptions: Global Economics and the Early Modern English Stage (Philadelphia, 2008), https://doi.org/10.9783/9780812201925.

10 Linda Levy Peck, Consuming Splendor: Society and Culture in Seventeenth-Century England (Cambridge, 2005), 125.

11 Alison V. Scott, Literature and the Idea of Luxury in Early Modern England (London, 2014), 144, https://doi.org/10.4324/9781315592657.

12 Fergus Linnane, Madams: Bawds \& Brothel-Keepers of London (Gloucestershire, 2005), 6.

13 Howard, 'Mastering Difference', 112.

14 Marjorie Rubright, 'Going Dutch in London City Comedy: Economies of Sexual and Sacred Exchange in John Marston's The Dutch Courtesan (1605)', English Literary Renaissance 40.1 (2010), 95, https://doi.org/10.1111/j.1475-6757.2009.01062.x.

15 Andrew Fleck, 'The Custom of Courtesans and John Marston's The Dutch Courtesan', American Notes and Queries 21.3 (2008), 14. For further discussions of Franceschina's cosmopolitanism via her linguistic skill, see Howard, 'Mastering Difference', 110-12; Rubright, 'Going Dutch', 97-100; Andrew Fleck, “'Ick verstaw you niet”: Performing Foreign Tongues on the Early Modern English Stage', Medieval and Renaissance Drama in England 20 (2007), 204-21; Alice Leonard, "Enfranchised" Language in Henry V and The Dutch Courtesan', Cahiers Elisabethains 84 (2013), 1-11, https://doi.org/10.7227/ce.84.1.2; and Janghyun Nam, 'The Whore of Babylon: Language and Identity in John Marston's The Dutch Courtesan', Shakespeare Review 50.3 (2014), 541-62, https://doi.org/10.17009/shakes.2014.50.3.006.

16 Oxford English Dictionary (OED), s.v. 'creature', n. 4.

17 The inconstant woman appears often in early modern plays, and framing Franceschina's ability to transform herself to appeal to new clients as a 'turn' connects to potential conversations about economic implications of the sexualized religious conversions well-covered in early modern scholarship. For example, Othello says of Desdemona, 'she can turn, and turn, and yet go on, / And turn again' (4.1.50-1), raising questions about the efficacy and artifice of serial conversions; William Shakespeare, Othello, in The Norton Shakespeare, ed. Stephen Greenblatt, Walter Cohen, Jean E. Howard, and Katharine Eisaman Maus (New York, 2008). For discussion of these lines in conversion narratives, see Jane Hwang Degenhardt, 'Dangerous Fellowship: Universal Faith and its Bodily Limits in The Comedy of Errors and Othello', in Islamic Conversion and Christian Resistance on the Early Modern Stage (Edinburgh, 2010), 32-72, 64-7, https://doi.org/10.3366/edinburgh/9780748640843.003.0002 and Daniel Vitkus, 'Othello Turns Turk', in Turning Turk: English Theater and the 
Multicultural Mediterranean, 1570-1630 (New York, 2003), 77-106, https://doi. org/10.1007/978-1-137-05292-6 4. For a discussion of turning, (re)turning, nonlinear, and contradictory processes in sexual conversion narratives, see Spiess, Shakespeare and the Making of Early Modern Whoredom.

18 For the ubiquity of courtesan songs as siren-like, see Martha Feldman, 'The Courtesan's Voice: Petrarchan Lovers, Pop Philosophy, and Oral Traditions', in The Courtesan's Arts: Cross-Cultural Perspectives, ed. Martha Feldman and Bonnie Gordon (Oxford, 2006), 103-23. For discussion of courtesan songs as sexually seductive, see Gustav Ungerer, 'The Viol da Gamba as a Sexual Metaphor in Elizabethan Music and Literature', Renaissance and Reformation 8.2 (1984), 79-90.

19 Katrine K. Wong, “'A Damnd Divel, or an Angel?”: Women and Music', in Music and Gender in English Renaissance Drama (New York, 2013), 31, https://doi. org/10.4324/9780203080801. See also Elizabeth Kenny, 'Revealing Their Hand: Lute Tablatures in Early Seventeenth-Century England', Renaissance Studies: Journal of the Society for Renaissance Studies 26.1 (2012), 112-37, https://doi.org/10.1111/ j.1477-4658.2011.00792.x.

20 Jonathan Gil Harris discusses the metaphors of syphilis in mercantilist writing to think about the damaging impact of global exchange. Although he does not address whores explicitly, their kind of marketplace seduction is the source of the disease that Harris discusses. See Harris, Sick Economies: Drama, Mercantilism, and Disease in Shakespeare's England (Philadelphia, 2004), 29-51, https://doi. org/10.9783/9780812202199.

21 Forman, Tragicomic Redemptions, 40,

22 David Crane points to moments when this dynamic might be particularly effective in 'Patterns of Audience Involvement at the Blackfriars Theatre in the Early Seventeenth Century: Some Moments in Marston's The Dutch Courtesan', in Plotting Early Modern London, ed. Dieter Mehl, Angela Stock, and Anne-Julia Zwierlein (Aldershot, Hampshire, 2004), 97-107.

23 For more on the similarities between theatre and prostitution, see Joseph Lenz, 'Base Trade: Theater as Prostitution', English Literary History 60.4 (1993), 833-52, https:// doi.org/10.1353/elh.1993.0005.

24 Stephen Gosson, The School of Abuse (London, 1587; sтc: 12097), B6v.

25 Howard, 'Mastering Difference', 115.

26 Rubright, 'Going Dutch', 107

27 Garrett A. Sullivan, Jr explores the mixedness of the Mulligrubs' tavern as a response to the 'the perceived rampant commercialization of urban life' in "All Thinges Come into Commerce": Women, Household Labor, and the Spaces of Marston's The Dutch Courtesan', Renaissance Drama 28 (1997), 19-46, https://doi.org/10.1086/ 
rd.27.41917326. Marjorie Rubright, too, emphasizes the variety of adulterations religious, culinary, and sexual - at work in the Mulligrubs' tavern: 'By the play's conclusion Mistress Mulligrub's religious affiliation has joined with her professional role as a public house keeper to set in motion an imputation of sexual transgression articulated in terms of culinary mixedness. So, too, her culinary transgressions are depicted as a religious sin'; Rubright, 'Going Dutch', 110. 
